\title{
Liszt's Hungaro-European Synthesis Comments Relating to the Cultural-historical Context of The Three Kings March of the Christus oratorio
}

\author{
Imre KovÁcS \\ Department of Art History \\ Pázmány Péter Catholic University \\ Egyetem u. 1, H-2087 Piliscsaba - Budapest, Hungary \\ E-mail: ikovacshu@yahoo.co.uk
}

(Received: March 2016; accepted: June 2016)

\begin{abstract}
It is evident that The Three Kings march of the Christus oratorio by Liszt is a verbunkos associated with the Eastern identity of Hungarians. What message did Liszt, who used musical motifs very consciously, wish to convey to the people of his time? I will approach the question not from a musicological aspect, but in the form of a cultural-studies type research. On the basis of the studies of Jácint Rónay and János Erdélyi dealing with national characterology, I wish to highlight how the Hungarian national identity and the myth of Eastern origin were related. I shall also examine in my paper paintings that bear close connection with the piece in question. Among these, Adoration of the Magi by Stephan Lochner is of vital importance, as according to the biographer of Liszt, Lina Ramann, it was the inspirational source of the movement in question of the Christus oratorio. The study attempts to find an answer to the relationship between the Lochner painting and The Three Kings march as well; and we shall see that it is also related to the question of the Eastern identity of the Hungarians.
\end{abstract}

Keywords: Franz Liszt, Christus oratorio, Stephan Lochner, Ary Scheffer, Félicité de Lamennais

The present study aims to approach The Three Kings march of the Christus oratorio in a so called cultural-studies type analysis. Its aim is twofold. On the one hand, to provide additional information through the particular viewpoint of Liszt to one of the cardinal problems of the era, the question of nations, while on the other, to show what role fine arts played in the creative process of the composer. 
The Three Kings march of the Christus oratorio - the fifth movement of the first part of the composition - that is the Christmas oratorio - composed by Liszt between 1861 and 1863 has already been subject to scholarly research. Earlier on Adrienne Kaczmarczyk devoted an entire study to the subject, providing this present study an indispensable starting point. ${ }^{1}$ The study was based on the methodological starting point - also shared within the present work - that for a more differential understanding of the part of the composition in question a cultural historical approach reaching beyond the narrower, musical analysis is required. In researching the creative method of Liszt, who considered visual and literary inspiration an integral part of his work, the application of such a complex, interdisciplinary method could prove fruitful. ${ }^{2}$ Nevertheless, the argumentation of a musicological study written eighty years ago cannot be denied: by uncovering inspirational elements other than musical ones "only the ideological content of the musical work [by Liszt] can be derived, but not the hows of musical realization."

Let us follow first the train of Kaczmarczyk's thought, accompanied by some remarks. Even those not really accustomed to romantic music will no doubt realize the fact that Liszt accompanies The Three Kings with a verbunk march. This can be surprising on first hearing within the context of the Christian thematic of the Christus oratorio and Western musical traditions. However heterogeneous the composition is in style, the verbunk still remains a foreign body within. Of course, Liszt often used Hungarian stylistic elements, but he applied them in works having Hungarian themes. ${ }^{4}$ Thus Kaczmarczyk is right in asking: What meaning did Liszt, who was always especially conscious of using musical motifs, wish to confer to the Hungarian musical element here? ${ }^{5}$

The question cannot be answered without shortly referring to the role verbunk played in the formation of Hungarian national identity. Originally it was a heroic-pathetic male dance to the accompaniment of Gypsy bands during military recruitment, the heyday of which was from about 1790 to the 1830 s. ${ }^{6}$ Liszt and

1. Adrienne Kaczmarczyk, "Ungarische Dreikönige. Franz Liszts Oratorium Christus," in Liszt und Europa, hrsg. Detlef Altenburg und Harriet Oelers (Laaber: Laaber, 2008), 113-144.

2. The problem of Liszt and the arts only became a prominent research field in recent years. See the 2011 international conference organised by the Hungarian Academy of Sciences, Institute of Musicology (Liszt and the Arts), the proceedings of which appeared in Studia Musicologica 54/1 (March 2013), 54/2 (June 2013), 54/4 (December 2013), 55/1-2 (June 2014) and related exhibition at the Museum of the Institute of Musicology, Hungarian Academy of Sciences. Mária Eckhardt, Anna Baranyi, Adrienne Kaczmarczyk, Liszt and the Arts. Memorial exhibition on the 200th anniversary of the birth of Ferenc Liszt, ed. László Gombos (Budapest: Hungarian Academy of Sciences, Research Centre for the Humanities, 2012).

3. Zoltán Gárdonyi, "Liszt Ferenc magyar stílusa" [The Hungarian style of Ferenc Liszt], in A Magyar Nemzeti Múzeum zenetörténeti kiadványai (Music Historical Publications of the Hungarian National Museum), ed. Kálmán Isoz and Dénes Bartha (Budapest: Országos Széchényi Könyvtár, 1936), 11.

4. Crucial to the problem is: Gárdonyi, Liszt, 1-55.

5. Kaczmarczyk, "Ungarische Dreikönige,” 302.

6. László Felföldi, “A tánckultúra Magyarországon. Nemzeti táncaink: verbunk és czardas,” [Dance culture in Hungary. Our National Dances: verbunk and czardas], in Magyar Kódex 4. Reformkor és kiegyezés. 
his contemporaries believed it to be ancient Hungarian music and as such it was considered one of the main embodiments of Hungarian national character.

Its role in the creation of a national identity is well attested by the dedication at the beginning of the verbunk dance collection entitled Hungarian Songs from Veszprém County published in 1824. According to the dedication, the aim of the collection is

not only to save the best pieces in the manuscripts from sinking into oblivion [...] but also to augment the development of our national feeling this way too, as we wish the national character to shine in these songs put forth to the world. ${ }^{7}$

Sources often reported on the exotic-Eastern character of the verbunk for the Western ear. This corresponded to the myth of the Eastern origins of Hungarians derived from the Hun-Hungarian kinship theory, which was a more or less generally accepted idea at the time of Liszt. ${ }^{8}$ As the Hungarian poet, Csokonai wrote in Dorottya:

All Hungarian hearts immediately rouse,

Ignited by their ancient, natural light,

They arrange their bodies in majestic posture,

Paying attention to their manly looks;

In them the haughty pride of Asia,

Decorates the pretty modes of Europe. ${ }^{9}$

The above description leads us to our topic, since Csokonai talks of a duality here: an orientalism identical to the Hungarian people's identity, which however, is unique in the eyes of Western people. ${ }^{10}$ Such uniqueness can of course mean a pejorative sense of strangeness, as it appears from the opinion of a contemporary

Magyarország müvelödéstörténete, 1790-1867. [Hungarian codex 4. Reform Age and the Compromise. The cultural history of Hungary 1790-1867], ed. József Szentpéteri (Budapest: Kossuth, 2000), 274-276.

7. Quoted in Liszt Ferenc és a „czigány zene” (Franz Liszt and “Gypsy music”), Exhibition Catalogue, ed. Péter Szuhay and Krisztina Pálóczy (Budapest: Museum of Ethnography, 2011), 5.

8. Sándor Eckhardt, "A magyarság külföldi arcképe" [Foreign portrait of the Hungarian people], in $M i$ a magyar? [What is Hungarian?], ed. Gyula Szekfü (Budapest: Magyar Szemle könyvei, 1939), 94-100; Nóra Veszprémi, "Nemzeti mitológiák" [National mythologies], in XIX. Nemzet és müvészet. Kép és önkép [XIX. Nation and art. Image and self-image], Exhibition Catalogue, ed. Erzsébet Király, Enikő Róka, Nóra Veszprémi (Budapest: Hungarian National Gallery, 2011), 297-304.

9. Mihály Csokonai Vitéz, Dorottya vagyis a dámák diadala a fársángon. Furcsa vitézi versezet négy könyvben (1798) [Dorottya that is the triumph of the ladies at carnival. Strange valiant poem in four books] (Budapest: Szépirodalmi Kiadó, 1983), 39.

10. On orientalism in nineteenth-century Hungary, see Géza Staud, Az orientalizmus a magyar romantikában [Orientalism in Hungarian Romanticism] (Budapest: Terebess, 1931); Katalin Sinkó, “Orientalizáló életképek" [Orientalizing genre paintings], in Müvészet Magyarországon, 1830-1870 [Art in Hungary 18301870], vol. 1, Exhibition Catalogue, ed. Júlia Szabó, György F. Széphelyi (Budapest: MTA Mủvészettörténeti Kutatócsoport, 1981), 98-106. 
in relation to The Three Kings march. Including it here is instructive to us because it also contains the reply Liszt made to it.

The composer recalled in the 1880 s as a German musician standing near him expressed his displeasure:

Der ungarische Teil des Marsches chokierte seinerzeit Müller-Hartung sehr. Indessen hat Rubens auf seinem Bilde Flamänder gezeichnet, also kann auch ich einem meiner Magier einen gewichsten Schnurrbart geben. Das geniert mich gar nicht! ${ }^{11}$

There is nothing strange in the fact that the composer putting the unity of arts in the centre of his thinking puts forth an argument based on a fine art piece. If Rubens, who was brought up as an authority, could "update" the Three Kings as Flemish, then Liszt can also make them Hungarian with the help of the verbunk march thus eliminating the spatial and temporal distance between the Biblical story and his time. The metaphor is clear: Liszt wished to represent the Hungarians with the Hungarian music he considered ancient. ${ }^{12}$

However, it should be emphasized that the Hungarian march of the Christmas oratorio was embedded into a pastoral music medium rooted in Western musical tradition. By integrating verbunk in the European musical tradition, Liszt achieved a unique Hungarian-European synthesis. Hungarians represented by the Three Kings and the shepherd people of the time of Jesus merged into one another thus becoming the representatives of the repentant people of the Bible.

Still, how can the nation concept "echoed here" be characterized? A remark of the composer himself could provide a good starting point in this question. Referring to his father's job as head shepherd, Liszt writes about a symbolic identification with the shepherds of the oratorio with regards to the 1873 premier of the Christus oratorio. ${ }^{13}$ His remark is more than the typical picturesque speech so characteristic of him; Herder's idealized natural existence is formulated here. The widespread romantic idea of the populace, according to which remote shepherd populations, as the major embodiments of moral purity, can provide a model of life bearing renewal to the civilized people of the age.

Studies concerning Hungarian nation characterology projected this idyllic concept of populace to the shepherds of the Great Plain region - coupled with the idea of the Hungarian people's Eastern identity. "We can find the characteristics of our

11. August Göllerich, Franz Liszt (Berlin: Marquardt, 1908), 157. Quoted in Kaczmarczyk, "Ungarische Dreikönige", 302. See also: Gárdonyi, Liszt, 38.

12. Kaczmarczyk, "Ungarische Dreikönige", 305.

13. Bernard Scharlitt-Wien, "Franz Liszt an Maria von Kalergis," Die Musik 11/1 (Oktober 1911), 31. 
nation in them in their original purity more than anywhere else, even the serious, eastern dignity considered generic"14 - wrote, for example, Jácint Rónay in 1847.

Linking Eastern identity and the pagan Hungarians was also a commonplace in these writings,${ }^{15}$ connecting the lowland landscape - considered archaic - and its inhabitants to the Eastern myth. This latter actually corresponds to the continuity theory based on Herder's people concept, which equates ancient and folkloric. The opinion formulated by János Erdélyi in his 1843 Images of a Journey can be considered typical:

We know from the holy story Jesus, Hagar and the whole Jewish nation in the wilderness; we have concepts of the Bedouins, Arabs of the desert; and as people of the East, we brought over a lot of it in our blood, because of which sons of the East turn towards us with kind emotions, or even with fondness. So it is no wonder that the best part of the Hungarian nation lives there, on the beautiful plain. ${ }^{16}$

When the idea of linking up the Hungarian people with the shepherds of the Holy Land was conceived by Liszt, he must have been thinking in such literary panels. ${ }^{17}$ There is no doubt that he had some knowledge of Hungarian nation characterology; a part of a letter written by him in 1856 is a proof of it. When he returned to Hungary again after eight years, he condensed his emotions of meeting his country into the following poetic image:

My heart was in tears at the border, when I caught sight of this simple image: the carefree shepherd sitting on his heels guarded by his sheep and oxen, because it seemed as if his animals were looking after him. ${ }^{18}$

14. Jácint Rónay, Jellemisme, vagy az angol, francia, magyar német, olasz, orosz, spanyol nemzet, nö, férfiú és életkorok jellemzése lélektani szempontból [Cognition of character, the characterization of the English, French, German, Italian, Russian, Spanish nations from the psychological aspect of gender and age] (Pest: Streibig, 1847). Quoted in Emese Révész, "A népéletkép szerepe a nemzeti jellem kidolgozásában az 1850-1870 közötti sajtóillusztráció példáján" [The role of folk genre in the formation of the national character based on newspaper illustrations between 1850-1870], Ars Hungarica 32/2 (2004), 294.

15. “[...] igazi attila-fajta magyar vér, pogánytermés, ki még az eleven ördögtől sem fél” [...true, Attila-type Hungarian blood, pagan origin, who is not afraid even from the devil himself] - wrote Imre Vahot, for example. Imre Vahot, "A hortobágyi puszta és a csikós" [The Hortobágy puszta and the wrangler], in $M a$ gyarföld és népei eredeti képekben [The Hungarian land and people in original images], ed. Elek Fényes and János Luzzenbacher, vol. 2/7 (1856), 17. Quoted in Révész, A népéletkép, 294.

16. János Erdélyi, "Úti képek" [Images of a journey], in idem, Úti levelek, naplók. [Letters, diaries of a journey], ed. Ilona T. Erdélyi (Budapest: 1985), 42-43. Quoted: Erzsébet Király "A nemzeti képzelettől a képalkotó nemzetig. Eszmék a magyar nemzet bölcsője körül," [From the national imagination to the image forming nation. Ideas around the cradle of the Hungarian Nation.] XIX. Nemzet és Müvészet, 131.

17. Adrienne Kaczmarczyk believes that Kelet Népe (People of the East) by István Széchenyi published in 1841 had a more direct impact on Liszt. Kaczmarczyk, „Ungarische Dreikönige,” 306-308.

18. In this letter to Carolyne Sayn-Wittgenstein, Liszt gives a detailed account of the customs of Hungarians. Franz Liszt's Briefe, hrsg. von La Mara (Leipzig: Breitkopf und Härtel, 1893-1905), Bd. 4, 314. 
Liszt's words suggest that in his eyes the Hungarian shepherd was almost not a reality, but a figure beyond its own reality. Rather a "phenomenon," which enabled the composer to conjure up the characteristic features of the stereotype image created of the shepherd: the carefree brooding of the melancholic figure. The statue by Miklós Izsó, which later became famous under the title Sad Shepherd (1862) is the symbolic embodiment of the folk character ${ }^{19}$ well known to us from the descriptions in contemporary Hungarian press. ${ }^{20}$

\section{2.}

A letter written by the composer might help us unfold the ideological background of the Christmas Oratorio, as it provides us with a lead concerning the interpretation of the Biblical story by Liszt. He wrote to Carolyne Sayn-Wittgenstein on 6 January 1872 the following:

I shall be in better company among the "shepherds" who heard the voice of the Angel professing peace to men of good will, and whom the wise kings admitted to their company [...]. And thus shall we proceed at the light of the Star of Bethlehem, climbing the stations of the Golgotha, and praising the God of justice and mercy. ${ }^{21}$

Although the Three Kings (Matthew 2.9-10) and the shepherds (Luke 2.15) receiving their calling independently did not go to Bethlehem together, they are formed into one group by Liszt. They are all the children of the converted people accepting the divine inspiration of God, who follow their assigned course providing a model for their peers joining them - beyond space and time. The inspiration provided by the Star of Bethlehem is thus nothing less than a Christian life path allegory pointing beyond the Biblical story and endowed with a community dimension, designating Liszt's own circumstances as well. This belonging to the people coupled with an orientation towards God was Liszt's artistic stance, since - as he put it in his 1835 ars poetica,

19. XIX. Nemzet és Müvészet, cat. IV. 2, 21.

20. "We can hardly imagine a shepherd other than in the field, the open puszta; on top of a sand mound, leaning on his stick, his eyes probing into the distance, pondering without thinking...," in Vasárnapi Újság (18 October 1868), 500. Quoted in Emese Révész, "Nemzeti identitás a 19. századi populáris grafikában” [National identity in nineteenth-century graphic art], in XIX. Nemzet és Müvészet, 65.

21. Franz Liszt's Briefe, Bd. 6, 322. Quoted in Kaczmarczyk, „Ungarische Dreikönige,” 323. 
in the past and even more so in our days, music should focus on the PEOPLE and GOD, create a bond between them, thus ennobling and consoling mankind while blessing and praising God. ${ }^{22}$

In the "light" of the above, it is not surprising that in the fifth movement of the Christmas Oratorio the Star of Bethlehem taking shape after the verbunk march is a "true inspiration" according to Paul Merrick. ${ }^{23}$ We are faced with a program like representation here, as Liszt copied Mathew 2.9 into the score: "and, lo, the star, which they saw in the East, went before them, till it came and stood over where the young child was."

Since The Three Kings march received a distinctively Hungarian music mark with the verbunk allusion, the Star of Bethlehem can be interpreted having a double reference. Besides showing the way to the Three Biblical Kings, the phenomenon also highlighted the right direction for Hungarians that is the path of Christianity. What has been defined in general terms above becomes practically tangible here: with the appearance of the Star of Bethlehem a transformation is realised, meaning the "musical Christianization" of the Hungarians.

At this point, it is worth drawing into the realm of this study the painting entitled The Three Magi by Ary Scheffer painted in 1844 (Plate 1). ${ }^{24}$ The painting, which decorated the Weimar home of Liszt and the princess Carolyne Sayn-Wittgenstein, the Altenburg, is an iconographic rarity and created great sensation at the time. His contemporaries recognised in the guise of the Biblical king facing the Star of Bethlehem the hidden portrait of Liszt. As it has been shown earlier, the composer - in harmony with the general artist role concept of the age, and his own ars poetica - appears here as the inspired prophet of art. ${ }^{25}$

Originally, the painting had a pair of identical size depicting the Annunciation to the shepherds' scene (Plate 2). ${ }^{26}$ Their mutual compositional element is the holy inspiration represented by radiant light, as a result of which the young king (Liszt) and the shepherds undergo transformation. This latter painting was not owned by Liszt, however, Liszt undoubtedly knew from Scheffer, who was a good friend of the composer's and paid several visits at the Altenburg, that originally

22. "De la situation des artistes, et de leur condition dans la socété," in Franz Liszt, Sämtliche Schriften, hrsg. von Detlef Altenburg, Bd. 1: Frühe Schriften, hrsg. von Rainer Kleinertz (Wiesbaden/Leipzig/Paris: Breitkopf und Härtel, 2000), 58.

23. "The new theme that appears at this point is a real inspiration." Paul Merrick, Revolution and Religion in the Music of Liszt (Cambridge: Cambridge University Press, 1987), 192.

24. Leo Ewals, Ary Scheffer. Sa vie et son oeuvre (Nimegue: Katholieke Universiteit, 1987), 297.

25. Imre Kovács, "The Portrait of Liszt as an Allegory of the Artist in Ary Scheffer's Three Magi," Studia Musicologica 49/1-2 (2008), 81-104.

26. Leo Ewals, Ary Scheffer (1795-1858). Gevierd Romanticus. Exhibition Catalogue, Dordrechts Museum. (Zwolle: Waanders Uitgevers, 1995), 243-244. 
Plate 1 The Three Magi (1844) by Scheffer (Private Collection)

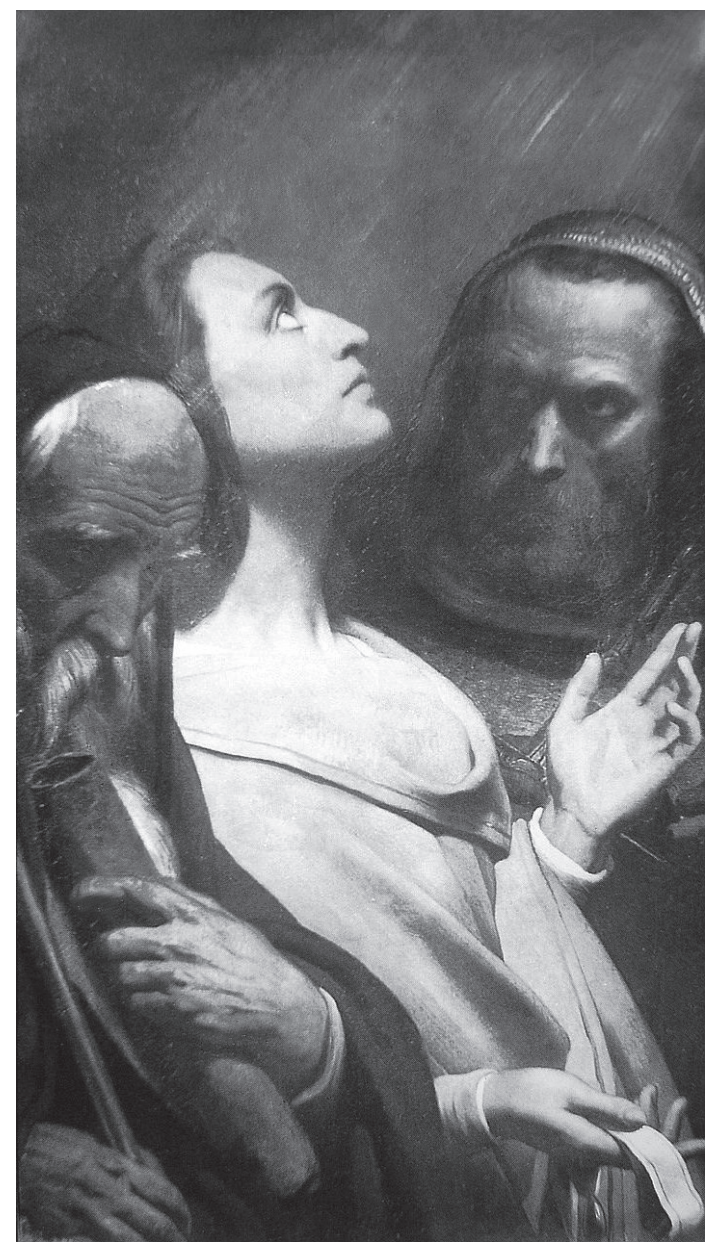

the two paintings belonged together. ${ }^{27}$ When the composer was in Rotterdam in 1854, he definitely saw the painting that was held in high esteem at the time, and even glorified in a poem, in the private collection of Abraham Nottebohm. ${ }^{28}$

The supposition that there is a rather close connection between the ideologies behind the two paintings and the Christmas Oratorio does not seem too bold after all. They are joined by the world view, which originates with the painter and the composer's mutual mentor, Abbé Lamennais's Christian socialist ideology cen-

27. On the friendship between Liszt and Scheffer, see Leo Ewals, "Beroemde tijdgenote van Scheffer. Franz Liszt (1811-1886)," Bulletin Dordrechts Museum 11 (1986), 22-24.

28. Ewals, Ary Scheffer, 220. There is also a version painted by Ary Scheffer which belongs together today as well. On this see: http://www.arcadja.com/auctions/en/scheffer_ary/artist/25862/(accessed February 2015). 
Plate 2 Annunciation to the shepherds (1844) by Scheffer (Private Collection)

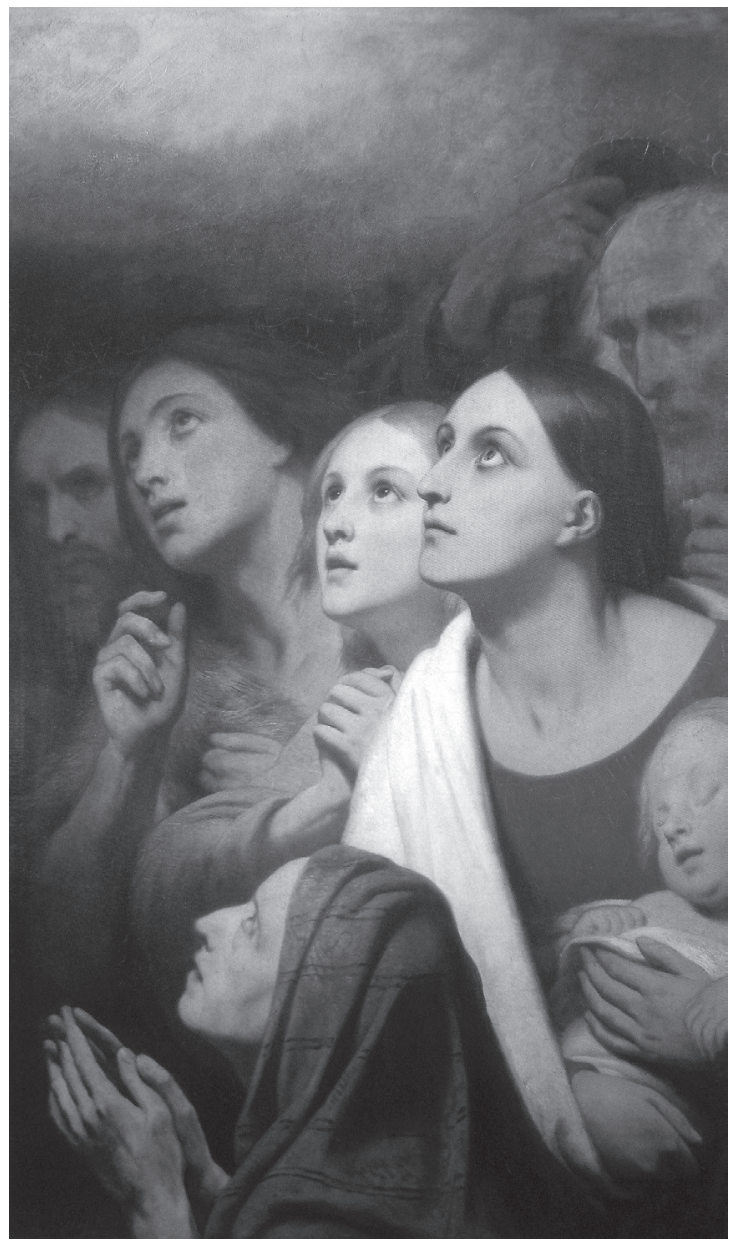

tring on the people and God. ${ }^{29}$ This explains in essence the similar people concept of the painting and the music: the strong emphasis laid in both works of art on the depiction of the people accepting divine inspiration and as a result transforming into a Christian community. Scheffer, just as Liszt, depicted the people as an idealized community of believers, with a deep feeling of empathy and solidarity towards the poor. ${ }^{30}$

29. Liszt introduced Ary Scheffer to Lamennais in 1844. On the relationship between Scheffer and Lamennais, see: Ewals, Ary Scheffer (1987), 112. On the relationship between Liszt and Lamennais, see Merrick, Revolution, 9-25.

30. The connection between image and music is made even stronger by the fact that the theme of the Annunciation to the shepherds is familiar from the Christmas oratorio as well; it is the title of the second movement. 
Plate 3 Stephan Lochner, Adoration of the Magi, c. 1440. (Cologne, Cathedral)

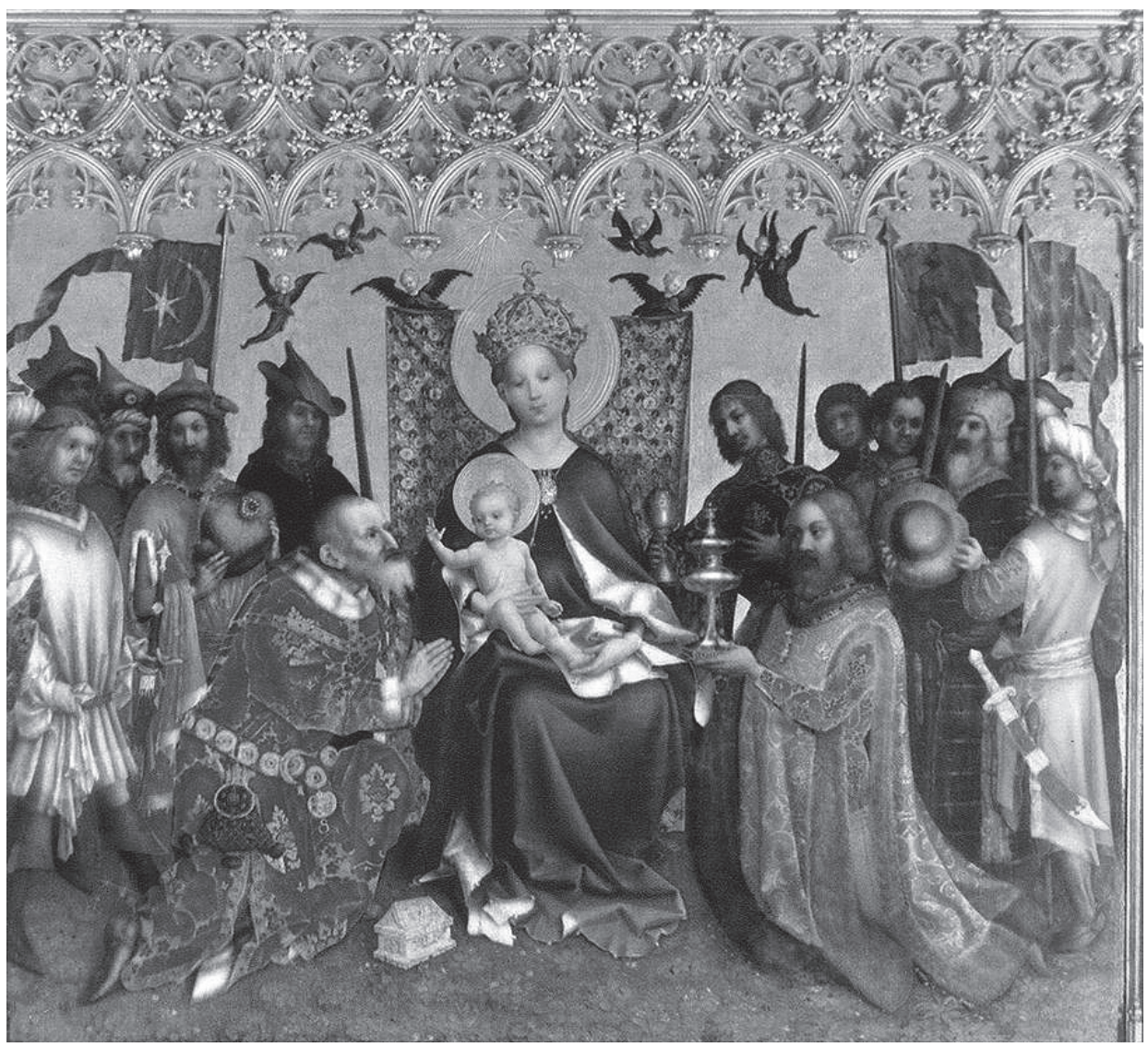

A striking similarity between the painting and the music is the Three Kings narrative functioning as a frame motif endowed with a personal touch, thus bearing an added meaning. The image narrative - as we have seen - refers to Liszt as an inspired artist prophet, while the musical one refers to the composer's people, the Hungarians marching in the light of the Star of Bethlehem and becoming Christians. These are interrelated artistic and social "role-identities" which are connected by holy inspiration - in line with the Christian life path of Liszt, and his artistic ideals.

The relationship between the paintings of Ary Scheffer and the piece of music under study can be described by the category of analogy stemming from mutual world view. There is, however, a painting, which - documentedly - was the source of inspiration behind The Three Kings movement. Lina Ramann mentions this painting: the Adoration of the Magi altarpiece in the Cologne Cathedral (Plate 3), 
in her biography also approved by the composer, when listing the paintings inspiring individual works by Liszt. ${ }^{31}$

Identifying of the painting is not particularly difficult. It was a well-known major piece in Liszt's age as well, Stephan Lochner's triptych, which was transported to the Cathedral of Cologne in 1809 , where it is still visible. ${ }^{32}$ We are in a more difficult situation if we inquire into the nature of this inspiration, since Ramann did not specify it.

Connecting the painting by Lochner to the last theme, the so called "treasure" theme of The Three Kings movement is convenient. The identification of the theme comes from Liszt himself, who copied into the autograph sheet the words of Mathew 2.11: "and when they had opened their treasures, they presented unto him gifts; gold, and frankincense and myrrh." ${ }^{33}$ It remains a question though, whether the relationship between painting and music, that is the nature of inspiration, can be described with simply the category of illustration arising from a thematic similarity. Hardly - Liszt must have seen something else too there. Lochner's painting must have caught his eyes with the splendour of a bygone age, with which not only the triumphant ending of the movement, the "tutti" accompanied by brass fanfares harmonized well, but also the archaic-oriental like music of the verbunk intermedium.

Liszt must have had some idea what his contemporary painters considered oriental appearance; the expressly oriental character of the figures appearing among the entourage of the kings must have caught his attention. ${ }^{34}$ In terms of our subject it is important whether Liszt considered these peak-capped attendants wearing beards and moustaches merely oriental, or maybe "Hungarian" as well. We might pose this question since millennial Hungarian historiography believed to have identified in the old king the hidden portrait of Sigismund of Luxemburg, King of Hungary and Holy Roman Emperor, while somewhat later the oriental looking figures were identified as his Hungarian entourage. ${ }^{35}$ Though a positive answer would

31. Lina Ramann, Franz Liszt, Artist and Man. 1811-1840 (London: Grasham Press, 1882), vol. 2, 372.

32. Brigitte Corley, Painting and Patronage in Cologne, 1300-1500 (Turnhout: Harvey Miller Publishers, 2000), 133-167. Corley contests the authorship of the painting from Lochner and identifies the painter as "Dombild Master."

33. Merrick, Revolution, 193.

34. On the orientalism of medieval paintings, see Ernő Marosi, Kép és hasonmás. Müvészet és valóság a 14-15. századi Magyarországon [Image and likeness. Art and reality in the fourteenth and fifteenth centuries in Hungary] (Budapest: Akadémiai, 1995), 57-66.

35. "Emperor Sigismund in the altarpiece of the Cologne Cathedral" (inscription under the reproduction of Lochner's painting). Antal Pór and Gyula Schönherr, Az Anjou ház és örökösei (1301-1439). A magyar nemzet története [The house of Anjou and its heirs, 1301-1439. The history of the Hungarian nation], ed. Sándor Szilágyi, vol. 3 (Budapest: Athenaeum, 1895), 584. "The entourage of the king [Sigismund of Luxemburg] is remarkable here. All have moustaches, and beards, with one exception, wearing pointed fur caps turned up in the back, the kind we know from the Illuminated Chronicle and other places to be worn by the Cumans. They can only be the depictions of the Hungarian lords in the entourage of the King." Henrik Horváth, Zsigmond király és kora [King Sigismund and his age] (Budapest: Budapest Székesfóváros, 1937), 24. 
obviously support our train of thought, as it would provide a visual analogy for giving a Hungarian tone to the march, nevertheless, by projecting back later sources to the age of Liszt, we would fall into the trap of being unhistorical. So further research is necessary in this regard. In any case, it is worth recalling: when Liszt made an apologetic comment concerning the Hungarian character of the march, it was not a coincidence that he brought his analogy from the field of painting.

We have seen by what means Liszt integrated the verbunk in Western music in the analyzed part of a composition. We can witness the creation of a Hungarian-European synthesis with a Christian ethos, which can just as well be interpreted as the special musical reflection of the Christian versus pagan Hungarian dispute. We can see the standpoint of the catholic Liszt in the ambivalent perception concerning the Hungarian nation, which sees the descendents of the pagan, barbarian Attila in our nation on the one hand, while on the other the defenders of Christian faith. ${ }^{36}$ Liszt provided his own nation a special role with the verbunk allusion: he identified the Hungarian nation - parallel with the renewal of the cult of Saint Stephen at the time - with the converted people who recognized the Saviour in Christ. ${ }^{37}$

36. This ambivalence can be detected in nineteenth-century Western historical representations of Hungarians as well. For this, see Katalin Sinkó, "Historizmus - antihistorizmus" [Historicism - anti-historicism], in Történelem - Kép. Szemelvények múlt és müvészet kapcsolatából Magyarországon [History - image. Excerpts from the relationship of the past and art in Hungary], exhibition catalog, ed. Ârpád Mikó and Katalin Sinkó (Budapest: Hungarian National Gallery, 2000), 106-107.

37. Closely related to the present topic is that Liszt planned a national oratorio that would have centred on the figure of Saint Stephen, who converted the pagan Hungarians. It was, however, never composed. See Peter Raabe, Liszts Schaffen (Stuttgart/Berlin: Cotta, 1931), 361. On nineteenth-century Saint Stephen cult, see Katalin Sinkó, “Árpád kontra Szent István” [Árpád versus Saint Stephen], in eadem, Ideák, motívumok, kánonok [Ideas, motifs, canons] (Budapest: Hungarian National Gallery, 2012), 156. 